\title{
Prader-Willi-like syndrome
}

INSERM

\section{Source}

INSERM. (1999). Orphanet: an online rare disease and orphan drug data base. Prader-

Willi-like syndrome. ORPHA:398073

Prader-Willi-like syndrome is a rare, genetic, endocrine disease characterized by manifestations of a Prader-Willi syndrome phenotype (including obesity, hyperphagia, hypotonia, psychomotor delay, intellectual disability, small hands/feet, hypogonadism, growth hormone deficiency and characteristic facial features) ocurring in the absence of 15q11-q13 genomic abnormalities. 